\title{
Presence and concentration of polycyclic aromatic hydrocarbons (PAHs) in sediments and organisms from Tampamachoco coastal lagoon and Tuxpan River, Veracruz; México.
}

\author{
Alfonso V. Botello \\ Instituto de Ciencias del Mar y Limnología: Universidad Nacional Autonoma de Mexico Instituto de \\ Ciencias del Mar y Limnologia \\ Guadalupe Ponce-Vélez ( $\sim$ ponce@cmarl.unam.mx) \\ Instituto de Ciencias del Mar y Limnología: Universidad Nacional Autonoma de Mexico Instituto de \\ Ciencias del Mar y Limnologia https://orcid.org/0000-0002-4901-0838

\section{Susana Villanueva F.} \\ Instituto de Ciencias del Mar y Limnología: Universidad Nacional Autonoma de Mexico Instituto de \\ Ciencias del Mar y Limnologia
}

\section{Research Article}

Keywords: Polycyclic aromatic hydrocarbons, Tampamachoco lagoon, Tuxpan river, sediments, fish, oysters

Posted Date: August 23rd, 2021

DOI: https://doi.org/10.21203/rs.3.rs-831814/v1

License: (c) (i) This work is licensed under a Creative Commons Attribution 4.0 International License. Read Full License 
Presence and concentration of polycyclic aromatic hydrocarbons (PAHs) in sediments and organisms from Tampamachoco coastal lagoon and Tuxpan River, Veracruz; México.

\author{
Alfonso V. Botello, Guadalupe Ponce-Vélez*, Susana Villanueva F. \\ Universidad Nacional Autónoma de México, Instituto de Ciencias del Mar y Limnología, Ciudad \\ Universitaria 04510 Ciudad de México, México
}

*Corresponding author.

E-mail address: ponce@cmarl.unam.mx (Guadalupe Ponce-Vélez)

\begin{abstract}
Polycyclic aromatic hydrocarbons (PAHs) have carcinogenic and mutagenic properties and their main origin in the environment is the burning of fossil fuels and organic material and they are considered high priority Persistent Organic Compounds (POPs). In the present study (March and August 2018) the concentrations of the 16 priority PAHs were analyzed in sediments and organisms (fish and oysters) in the estuarine-lagoon system Tuxpan-Tampamachoco, Veracruz; Mexico.

The analysis of these compounds was carried out by means of gas chromatography-FID and mass spectrometry. In March (dry season) the average concentration of PAHs in sediments was $0.86 \pm 0.39 \mu \mathrm{g} / \mathrm{g}$ and in August (rainy season) it was $1.14 \pm 0.45 \mu \mathrm{g} / \mathrm{g}$. During both collections, chrysene presented the highest total concentrations and a domain of the compounds with 4 benzene rings was observed, therefore, pyrolytic sources of contribution predominated. The highest concentrations of PAHs occurred in 2 stations located in the Tuxpan riverbed and both exceeded the threshold concentration to cause adverse effects to the benthic community.
\end{abstract}

The analysis of PAHs in organism tissues was carried out in 4 species of fish and one mollusk. In march, the species with the highest concentration was Bagre marinus with $88.87 \mu \mathrm{g} / \mathrm{g}$ and in august it corresponded to the Caranx hippos species with $26.82 \mu \mathrm{g} / \mathrm{g}$ and the compound determined with the highest presence was benzo(b)fluoranthene.

Finally, the tendency of accumulation of PAHs in the evaluated matrices was: fish> sediments> mollusks.

Keywords: Polycyclic aromatic hydrocarbons, Tampamachoco lagoon, Tuxpan river, sediments, fish, oysters.

\title{
Declarations
}

Not Applicable

\section{Introduction}

PAHs occur in air, land and water, from natural or anthropogenic sources, although the contribution from natural sources is minimal compared to emissions caused by humans, which are mainly produced by incomplete combustion processes (Mastandrea et al. 2005). The compounds originated by this process are introduced to marine and coastal environments through atmospheric transport that drives pollutants from the continents to coastal areas and from there to the open sea (Gambaro et al. 2009).

In the present work, the concentrations and types of PAHs present in sediments, their origin, as well as the concentrations in tissue of aquatic specimens (fish and molluscs) were determined since some authors such as 
Quintero and Díaz (1994) have reported that in fish muscle tissue the half-life of hydrocarbons is longer than in other tissues and in mollusks because they are considered as indicators of contamination in aquatic environments due to their limited capacity to metabolize pollutants (Kim et al. 2001) .

In the case of marine-coastal environments such as the Tampamachoco lagoon, Veracruz; bivalves are continuously exposed to a wide variety of contaminants associated with the dissolved and particulate phase (Chu et al. 2002) as well as various nectonic and plantonic species that gradually bioaccumulate and transfer the ingested PAHs to the next trophic link. For this reason, the presence of these compounds in the lagoon area and the Tuxpan river constitutes a potential source of damage to aquatic organisms and eventually to man; Due to the fact that diverse environmental, industrial, social and economic factors converge in this area.

The quantification of hydrocarbons was carried out considering the water regime of both seasons: dry (marchjune) and rainy (august-november) in the study area. Potential sources of these compounds include: port activity, electricity generation, gasoline reception and storage, as well as the discharge of industrial and municipal wastes into the Tuxpan River. On the other hand, the natural processes that can define the conditions of dispersion and presence in the environment present seasonal conditions, including the volume of discharge from the Tuxpan River, tidal cycles, coastal currents and waves.

\section{Study Area}

The estuary-lagoon system of Tuxpan-Tampamachoco is located in the north of the state of Veracruz, northeast of the town of Tuxpan, between $20^{\circ} 18^{\prime}$ north latitude and $97^{\circ}$ and $98^{\prime}$ west longitude. The estimated lagoon area is $57.5 \mathrm{~km}^{2}$, with an approximate length of $10 \mathrm{~km}$ and $3 \mathrm{~km}$ in its widest part (Botello 1994). The lagoon lacks notable bathymetric features, except for the channel that runs in a north-south direction and that continues until its communication with the Tuxpan estuary, with an average depth of $2.5 \mathrm{~m}$. In the northern part of the lagoon there are two channels, the new and the old, with approximately $4 \mathrm{~m}$ depth that link to the north with the Galindo bar and the Tamiahua lagoon. Two collections were made in the study area, one during the month of March 2018 and another in August of the same year. Inside the lagoon, four sampling stations were located (E-1, E-2, E-3 and E-4) and in the lower course of the Tuxpan river three stations were located, one at the mouth of the lagoon (E5), on the shore of the estuary. Tumilco (E-6) and dock area (E-7) (Fig. 1). Each of the stations is subject to various anthropogenic pressures as shown in table 1.

Table 1. Location of sampling stations and probable sources of PAHs.

\begin{tabular}{|c|c|c|c|c|}
\hline Station & Latitude (N) & Longitude (W) & Depth (m) & Probable source of PAHs \\
\hline E-1 & $21^{\circ} 01.47$ & $97^{\circ} 21.28$ & -3.38 & $\begin{array}{l}\text { The influence of the canals, the new and the old } \\
\text { motor boats Gas emissions from the city of } \\
\text { Tuxpan. }\end{array}$ \\
\hline E-2 & $21^{\circ} 0.445$ & $97^{\circ} 21.01$ & -1.0 & $\begin{array}{l}\text { The thermoelectric power plant motor boats Gas } \\
\text { emissions of the city of Tuxpan. }\end{array}$ \\
\hline E-3 & $21^{\circ} 59.51$ & $97^{\circ} 21.47$ & -3.0 & $\begin{array}{l}\text { The thermoelectric plant motor boats Gas } \\
\text { emissions from the city of Tuxpan. }\end{array}$ \\
\hline E-4 & $21^{\circ} 58.41$ & $97^{\circ} 20.25$ & -1.0 & $\begin{array}{l}\text { PEMEX facilities wastewater discharges motor } \\
\text { boats gas emissions from the city of Tuxpan. }\end{array}$ \\
\hline E-5 & $21^{\circ} 58.10$ & $97^{\circ} 19.41$ & -3.0 & \multirow{2}{*}{$\begin{array}{l}\text { PEMEX facilities transit of ships discharge from } \\
\text { the lagoon influence of the sea discharges from the } \\
\text { Tuxpan river basin gas emissions from the city of } \\
\text { Tuxpan. }\end{array}$} \\
\hline E-6 & $21^{\circ} 57.56$ & $97^{\circ} 19.11$ & -10 & \\
\hline E-7 & $21^{\circ} 57.25$ & $97^{\circ} 20.29$ & -8.0 & $\begin{array}{l}\text { Transit of ships docks area discharges from the } \\
\text { Tuxpan river basin gas emissions from the city of } \\
\text { Tuxpan. }\end{array}$ \\
\hline
\end{tabular}




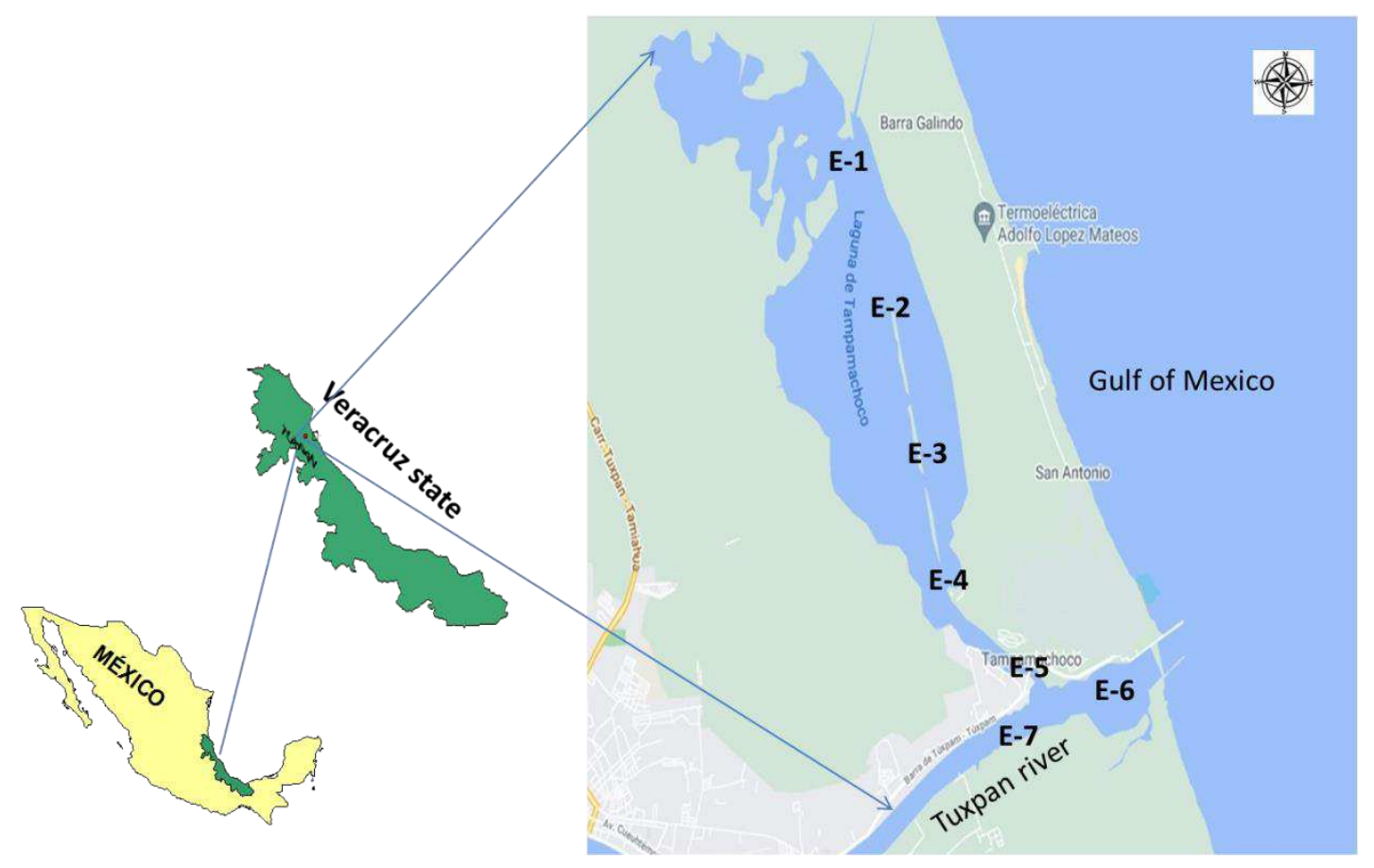

Fig. 1. Location of the sampling stations in the Tampamachoco lagoon in Tuxpan, Veracruz, Mexico.

\section{Methodology \\ Collection and analysis of sediments and organisms}

The sediments were collected by means of a van Veen dredge, obtaining the first $10 \mathrm{~cm}$ of the sedimentary column and with the help of a spatula a portion of the sample was taken and placed in glass jars previously washed and treated with pure acetone. The organisms were collected with fishing gear (nets) and the oysters collected by hand. The samples were kept frozen until the moment of analysis.

The methodology used to perform the PAHs analysis in sediments was that proposed by UNEP/IOC/IAEA (1992) and USEPA (2001). The sediments were dried at a temperature of $50^{\circ} \mathrm{C}$, then homogenized in a porcelain mortar and sieved through a $250 \mu \mathrm{m}$ mesh. In the case of mollusks, 25 specimens and 10 of each species of fish were taken from which the viscera were removed and only the muscle tissue was analyzed with method proposed for UNEP/FAO/IOC/IAEA (1993) and USEPA (2001). Weigh $3 \mathrm{~g}$ of dry, ground and sieved or freeze-dried sediment; place it on a Whatman No 2 filter paper disc previously washed into the teflon tubes of the microwave equipment; extraction is performed by EPA 3546 extraction method with 25 $\mathrm{mL}$ of hexane:acetone $(50: 50 \mathrm{v} / \mathrm{v})$ mixture a microwave-assisted procedure (MEA). Centrifuge the samples for $5 \mathrm{~min}$ at $1500-2000 \mathrm{rpm}$ to remove any sedimentary particles remaining in the extract. Concentrate the extract in rotoevaporator up to about 5-8 $\mathrm{mL}$ (the bath temperature should not exceed $30^{\circ} \mathrm{C}$ and the vacuum pump pressure should be $40 \mathrm{psi}$ ).

The qualitative and quantitative analysis was carried out with an Agilent 5890 Series II gas chromatograph equipped with a flame ionisation detector (FID) and the external standard method was used with a 5-level calibration curve $(2,5,10,15$ and $20 \mu \mathrm{g} / \mathrm{mL})$ of concentration of a standard solution mixture containing 16 priority PAHs; included reagent blanks, fortified blanks, and duplicate sediment samples as part of quality 
control in laboratory analysis. Limit of detection (LOD) for all PAHs was $0.01 \mu \mathrm{g} / \mathrm{g}$, the limit of quantification (LOQ) was between 0.01 and $0.02 \mu \mathrm{g} / \mathrm{g}$, the recovery was between 82 (Naphthalene) and $102 \%$ (Benzo[g,h,i]perylene) and the coefficient of variation ranged between 4 (Naphthalene) and $18 \%$ (Phenanthrene) (Ponce-Vélez 2012; Amador-Muñoz et al. 2020).

\section{Results and Discussion}

\section{Sediments}

The average concentration of the compounds detected in the sediments during the dry season (march) was $0.86 \pm 0.39 \mu \mathrm{g} / \mathrm{g}$, while the minimum concentration was $0.01 \mu \mathrm{g} / \mathrm{g}$. During the rainy season (august) the maximum concentration was $3.05 \mu \mathrm{g} / \mathrm{g}$ and the minimum concentration was $0.01 \mu \mathrm{g} / \mathrm{g}$ with an average value of $1.14 \pm 0.45 \mu \mathrm{g} / \mathrm{g}$.

Table 2 and 3 show the results of the compounds detected and not detected during the months of march and august (2018) of the 16 PAHs analyzed, as well as the sedimentary quality criteria established and used internationally for coastal environments, which are the threshold concentration (TEL or ISQG) from which harmful effects can be observed in the benthos caused by the toxicity of the sediments containing these pollutants. The reference concentrations most commonly used to approximate the probability of ecotoxicological risk in sediments are ERL (Effect Range Low) and ERM (Effect Range Median) (Buchman 2008). In general, it is observed that toxic effects in organisms occur rarely when < ERL, occasionally when ERL-ERM and frequently if > ERM (Long et al. 1995; CCME 1999; Buchman 2008).

A total of 16 compounds were found in the sediments throughout the annual cycle, of which 9 occurred in the dry season and 14 in the rainy season. During the month of march, the PAHs with the highest presence were chrysene and benzo(a)anthracene, the rest of the compounds were detected in 3 or fewer stations or were below the detection limit (Table 2). The station 6 presented the highest total concentration of PAHs with 3.08 $\mu \mathrm{g} / \mathrm{g}$ and the individual hydrocarbons with highest level was chysene with $3.05 \mu \mathrm{g} / \mathrm{g}$, and which exceeded the threshold and ERM concentration as observed in figure 2 and table 2; chrysene presented an average of $0.61 \pm$ $1.1 \mu \mathrm{g} / \mathrm{g}$ and a different distribution of values than benzo(a)anthracene, originated by a single extreme value that exceeds the range of values where most of the data is located (Fig. 2).

During the month of august (rain season) the presence of detected compounds increased, as observed in table 2. The highest total concentration of PAHs was recorded in station 7 with $3.67 \mu \mathrm{g} / \mathrm{g}$ and exceeded the threshold concentration $(1.68 \mu \mathrm{g} / \mathrm{g}$; Fig. 2) and the chrysene continues being the only compound with an average $(0.68 \pm 1.2 \mu \mathrm{g} / \mathrm{g})$ and interval of variation statistically different from the rest of the compounds, with a single extreme value (3.27 $\mu \mathrm{g} / \mathrm{g}$ ) (Fig. 3). Regarding the concentrations of the compounds, it was observed that in some stations chrysene, benzo(a)anthracene, dibenzo(a,h)anthracene, phenanthrene, fluorene, acenaphthylene and acenaphthene were superior to one or more of the established sedimentary quality criteria (Table 2).

According to the number of benzene rings of the PAHs, it was observed that during both collections the dominant compounds were presented in the following order: $4>6>5>3>2$. In both climatic seasons (dry and rainy) compounds of 4 rings, with variable concentrations, although always in greater quantity than the rest of the compounds (Fig. 2). The origin of PAHs made up of 4 benzene rings (chrysene, benzo(a)anthracene, pyrene) is mainly through pyrolysis (the burning of fossil fuels and emissions from the oil industry), which means that the contribution of hydrocarbons derived from the pyrolytic processes near the Tampamachoco lagoon and the Tuxpan river are continuous throughout the year, although the total amount contributed varies. 
Table 2. Concentrations of PAHs in surface sediments of the Tampamachoco-River Tuxpan lagoon system, Ver; in march and august 2018 (values in $\mu \mathrm{g} / \mathrm{g}$ dry weight) and sedimentary quality criteria.

\begin{tabular}{|c|c|c|c|c|c|c|c|c|c|c|c|c|c|c|c|c|c|c|}
\hline \multirow{3}{*}{$\begin{array}{l}\text { No. } \\
\text { RINGS }\end{array}$} & \multirow{3}{*}{ COMPOUND } & \multicolumn{14}{|c|}{ STATIONS } & TEL o & ERL & ERM \\
\hline & & \multicolumn{7}{|c|}{ MARCH } & \multicolumn{7}{|c|}{ AUGUST } & \multirow{2}{*}{\multicolumn{3}{|c|}{$\begin{array}{l}\text { (Long et al. 1995; } \\
\text { Buchman 2008) }\end{array}$}} \\
\hline & & E1 & E2 & $\mathbf{E 3}$ & E4 & $\mathbf{E 5}$ & E6 & E7 & E1 & E2 & $\mathbf{E 3}$ & E4 & $\mathbf{E 5}$ & E6 & E7 & & & \\
\hline 2 & Naphthalene (Nap) & N.D. & N.D. & N.D. & ND & N.D. & N.D. & N.D. & 0.02 & N.D. & N.D. & N.D. & N.D. & N.D. & N.D & 0.04 & 0.16 & 2.1 \\
\hline 2 & Acenaphthylene (Acy) & N.D. & N.D. & N.D. & ND & N.D. & N.D. & N.D. & 0.04 & 0.05 & 0.02 & N.D. & N.D. & 0.03 & 0.03 & 0.01 & 0.04 & 0.64 \\
\hline 2 & Acenaphthene (Ace) & N.D. & N.D. & N.D. & N.D & N.D. & N.D. & N.D. & 0.01 & 0.02 & N.D. & N.D. & N.D. & 0.02 & 0.01 & 0.01 & 0.02 & 0.5 \\
\hline 2 & Fluorene (Flu) & 0.03 & N.D. & N.D. & N.D & N.D. & N.D. & N.D. & 0.03 & 0.04 & 0.01 & N.D. & N.D. & 0.04 & 0.01 & 0.01 & 0.02 & 0.54 \\
\hline 3 & Phenanthrene (Phe) & 0.03 & N.D. & N.D. & N.D & 0.01 & 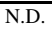 & N.D. & 0.07 & 0.1 & 0.01 & N.D. & N.D. & 0.08 & 0.03 & 0.09 & 0.24 & 1.5 \\
\hline 3 & Anthracene (Ant) & N.D. & N.D. & N.D. & 0.03 & N.D. & N.D. & N.D. & N.D. & 0.02 & N.D. & N.D. & N.D. & 0.03 & N.D. & 0.05 & 0.09 & 1.1 \\
\hline 3 & Fluoranthene (Fla) & N.D. & N.D. & N.D. & 0.11 & 0.05 & N.D. & N.D. & 0.02 & 0.06 & 0.01 & 0.03 & 0.02 & N.D. & 0.05 & 0.11 & 0.6 & 5.1 \\
\hline 4 & Pyrene (Pyr) & 0.02 & N.D. & N.D. & N.D & N.D. & N.D. & N.D. & 0.04 & 0.02 & 0.01 & N.D. & N.D. & N.D. & N.D. & 0.15 & 0.67 & 2.6 \\
\hline 4 & Benzo[a]anthracene (BaA) & 0.04 & 0.84 & N.D. & N.D & 0.04 & 0.03 & N.D. & $\begin{array}{ll}0.17 \\
\end{array}$ & 0.2 & 0.02 & $\begin{array}{l}0.03 \\
\end{array}$ & 0.09 & 0.1 & 0.1 & \begin{tabular}{|c|c|}
0.08 \\
\end{tabular} & 0.26 & 1.6 \\
\hline 4 & Chrysene (Cry) & 0.07 & 0.34 & 0.05 & 0.3 & 0.06 & 3.05 & 0.43 & 0.22 & 0.06 & 0.04 & 0.12 & 1 & 0.07 & 3.27 & 0.11 & 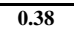 & 2.8 \\
\hline 4 & $\begin{array}{l}\text { Benzo[b]fluoranthene } \\
(\mathrm{BbF})\end{array}$ & N.D. & N.D. & N.D. & N.D & N.D. & N.D. & N.D. & $\begin{array}{l}\text { N.D. } \\
\end{array}$ & N.D. & N.D. & $\begin{array}{l}\text { N.D. } \\
\end{array}$ & N.D. & N.D. & N.D. & * & * & * \\
\hline 4 & $\begin{array}{l}\text { Benzo[k]fluoranthene } \\
(\mathrm{BkF})\end{array}$ & N.D. & N.D. & N.D. & N.D & N.D. & N.D. & N.D. & 0.05 & N.D. & N.D. & N.D. & N.D. & 0.06 & N.D. & $*$ & * & * \\
\hline 5 & Benzo[a]pyrene (BaP) & N.D. & N.D. & N.D. & N.D & N.D. & N.D. & N.D. & \begin{tabular}{|l|} 
N.D. \\
\end{tabular} & N.D. & N.D. & $\begin{array}{l}\text { N.D. } \\
\end{array}$ & N.D. & N.D. & N.D. & 0.09 & 0.43 & 1.6 \\
\hline 5 & $\begin{array}{l}\text { Indeno[1,2,3-cd]pyrene } \\
\text { (Ind) }\end{array}$ & N.D. & N.D. & N.D. & N.D & N.D. & N.D. & N.D. & 0.24 & 0.05 & N.D. & $\begin{array}{l}\text { N.D. } \\
\end{array}$ & N.D. & N.D. & 0.08 & * & * & * \\
\hline 5 & $\begin{array}{l}\text { Dibenzo[a,h]anthracene } \\
\text { (DahA) }\end{array}$ & 0.22 & N.D. & N.D. & N.D & N.D. & N.D. & 0.13 & \begin{tabular}{|l|} 
N.D. \\
\end{tabular} & 0.23 & 0.04 & $\begin{array}{l}\text { N.D. } \\
\end{array}$ & N.D. & 0.27 & 0.06 & 0.01 & 0.06 & 0.26 \\
\hline 6 & $\begin{array}{l}\text { Benzo[g,h,i]perylene } \\
\text { (BghiP) }\end{array}$ & 0.17 & N.D. & N.D. & N.D & N.D. & N.D. & N.D. & 0.16 & 0.13 & N.D. & N.D. & N.D. & 0.12 & $\begin{array}{l}0.03 \\
\end{array}$ & * & $*$ & * \\
\hline 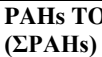 & TAL CONCENTRATION & 0.58 & 1.18 & 0.05 & 0.44 & 0.16 & 3.08 & 0.56 & 1.07 & 0.98 & 0.16 & 0.18 & 1.11 & 0.82 & 3.67 & 1.68 & 4.02 & 44.8 \\
\hline
\end{tabular}

$\mathrm{ND}=<0.01 \mu \mathrm{g} / \mathrm{g}$. ADVERSE BIOLOGICAL EFFECTS: ERL = Effects Range Low; ERM = Effects Range Median 


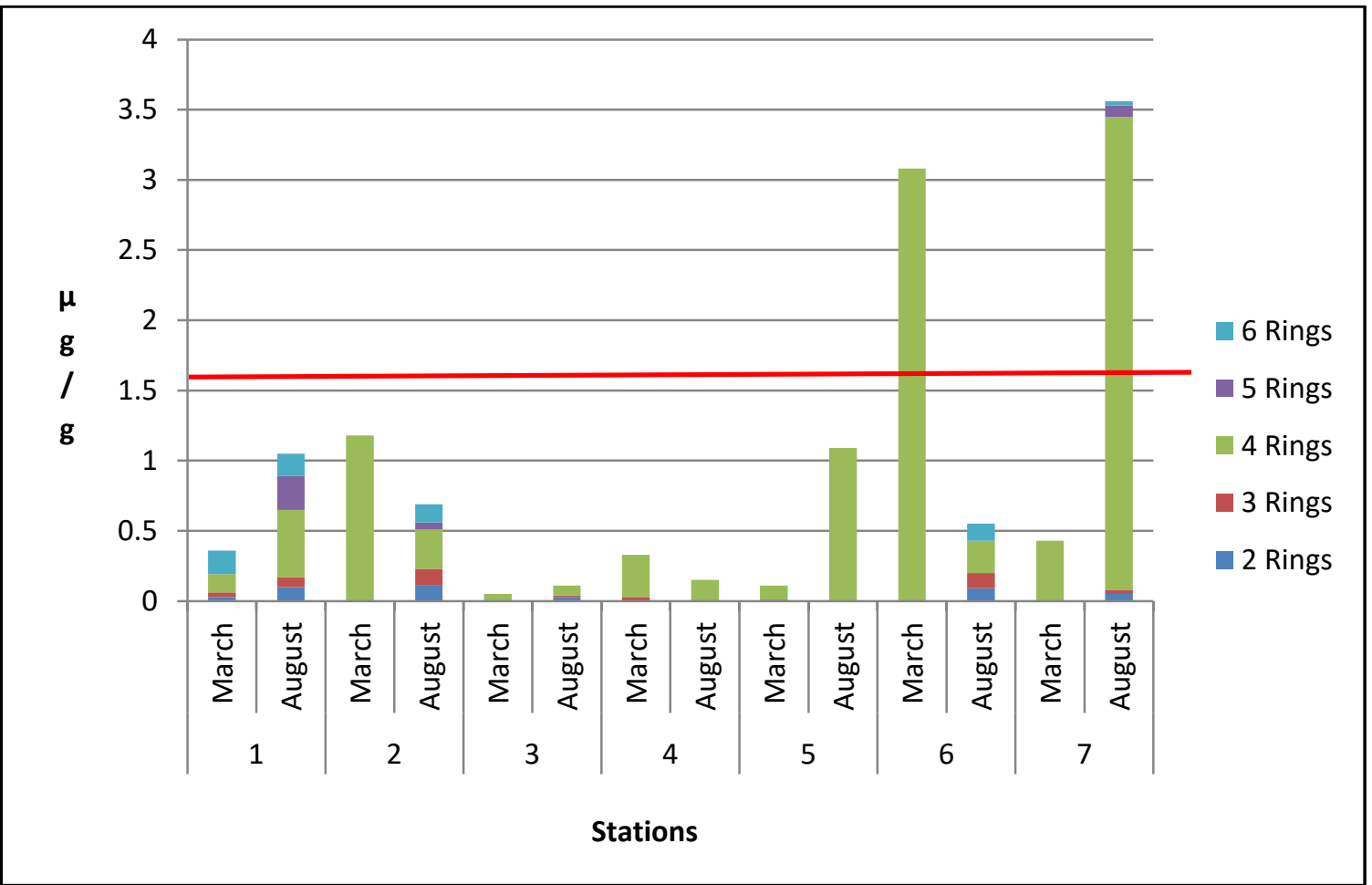

Fig. 2. Total concentrations of PAHs in sediments by station for the months of march and august, 2018 (Values in $\mu \mathrm{g} / \mathrm{g}$ dry weight).
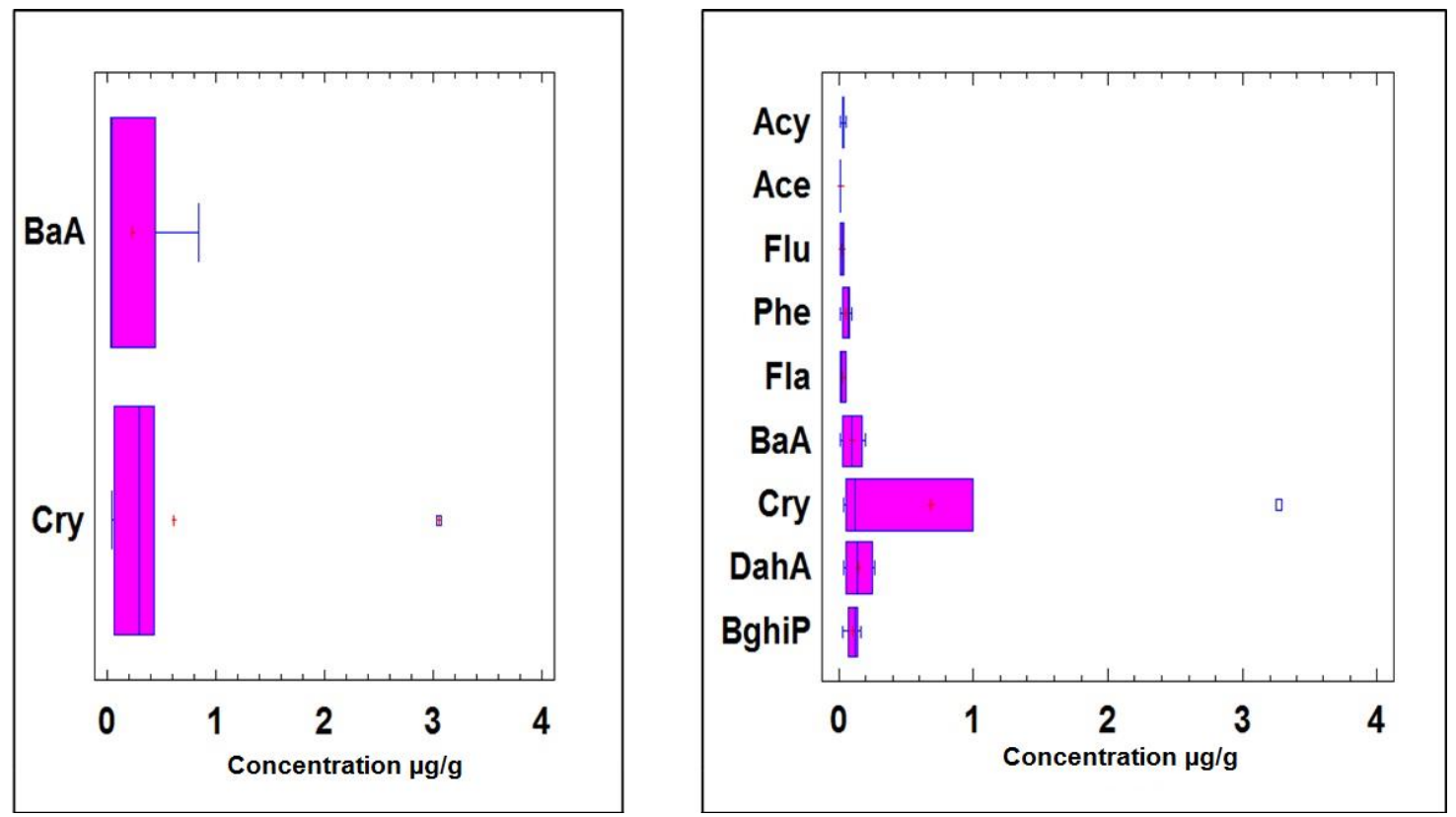

Fig. 3. PAHs individual in surface sediments above the detection limit in more than three sampling stations during march and august, 2018. 
To infer the possible sources of origin of PAHs in the sediment samples, the molecular indices were calculated to determine the relationship Ant/Ant+Phe, Fla/Fla+Pir and BaA/BaA+Cry (Budzinsky et al. 1997; Soclo et al. 2000; Yunker et al. 2002). According to the results obtained, it was generally observed that the pyrolytic sources were the dominant ones, however, petrogenic sources were also detected, and therefore, it is considered a mixed origin of PAHs with a predominance of pyrolytic sources in the sediments analyzed.

In various works, it has been reported that the presence and abundance of PAHs compounds formed by 4 and 5 aromatic rings in recently deposited lagoon-estuarine sediments, is similar to that found in atmospheric particles, which come from urban areas and can reach to the aquatic environment by atmospheric deposition and subsequent dragging by rain or surface water channels of urban and industrial effluents (Wu et al. 2003), a condition that is fulfilled in the case of the Tampamachoco lagoon where the sources occur described.

Comparatively, the average concentration of PAHs quantified during the present study was lower than that registered by Botello and Calva (1998) for the Tampamachoco lagoon and Tuxpan river and where they reported an average concentration of $4.48 \pm 1.84 \mu \mathrm{g} / \mathrm{g}$, with a concentration maximum of $9.39 \mu \mathrm{g} / \mathrm{g}$ in the rainy season, as well as, the diversity of compounds was lower than in the current study, only their origin coinciding (Table 3). This decrease may be due to the dredging activities that have been carried out along the channel, which could have caused the removal of the pollutants contained in the sediments out of the lagoon. When comparing the concentrations of PAHs obtained in this study with other studies carried out in various aquatic systems, it was observed that they are lower, as shown in table 3.

Table 3. Concentrations of PAHs reported in sediments of aquatic ecosystems in Mexico and other regions in the world.

\begin{tabular}{|l|c|c|l|}
\hline \multicolumn{1}{|c|}{ Area } & $\begin{array}{c}\text { Country or } \\
\text { Region }\end{array}$ & $\begin{array}{c}\text { Average concentration } \\
\text { PAHs }(\boldsymbol{\mu g} / \mathbf{g})\end{array}$ & \multicolumn{1}{|c|}{ Reference } \\
\hline Tampamachoco Lagoon, Ver. & México & 0.86 & March, 2018 this study. \\
\hline Tampamachoco Lagoon, Ver. & México & 4.48 & Botello and Calva (1998) \\
\hline Pueblo Viejo Lagoon, Ver. & México & 3.7 & Botello and Calva (1998) \\
\hline Tamiahua Lagoon, Ver. & México & 2.99 & Botello and Calva (1998) \\
\hline Sontecomapan Lagoon, Ver. & México & 7.54 & Calva and Botello (1999) \\
\hline La Mancha Lagoon Ver. & México & 6.72 & Botello et al. (2001) \\
\hline Salada Lagoon Ver. & México & 6.65 & Botello et al. (2001) \\
\hline Mandinga Lagoon, Ver. & México & 5.67 & Botello et al. (2001) \\
\hline El Llano Lagoon,Ver. & México & 5.0 & Botello et al. (2001) \\
\hline Chetumal Bay, Q.Roo & México & 1.45 & Noreña et al. (2007) \\
\hline Bahía Blanca & Argentina & $>15$ & Arias et al. (2010) \\
\hline Northern Irish Sea & England & 27 & Guinan et al. (2001) \\
\hline Guan River Estuary & China & $>25$ & He et al. (2014) \\
\hline NW Gulf of Mexico & United States & $>45$ & Sammarco et al. (2013) \\
\hline Cienfuegos Bay & Cuba & 30 & Tolosa et al. (2009) \\
\hline
\end{tabular}

Thus, it can be concluded that in the estuarine-lagoon system Tuxpan-Tampamachoco it is that the contribution of PAHs is continuous throughout the year, however it is greater during the rainy season and the pyrolytic sources are the dominant ones in both times of the year and in less quantity, the presence of a petrogenic component was detected in the sediments. The highest concentrations of PAHs were presented in the stations located in the Tuxpan riverbed in both collections. 
In most of the sediment samples, the total concentration of PAHs found in sediments was below the threshold concentration to cause adverse effects to the benthic community, except for the stations located in the Tuxpan riverbed. However, the values of various compounds such as chrysene, benzo(a)anthracene, dibenzo(a,h)anthracene were higher than the international sedimentary quality criteria, which could represent an environmental risk for the benthos and for those species that consume or filter sediments or absorb water contaminated with these compounds.

The levels of PAHs determined in this study are lower compared to those obtained in other aquatic systems in Mexico, however, it is necessary to establish a continuous surveillance of these compounds in the sediments to prevent damage to the benthic organisms that inhabit this system.

\section{Organisms}

In this study, the benthic organism Crassostrea virginica, presented the lowest concentrations of PAHs, in both collections compared to fish and sediments, which is contrary to that reported by various authors such as Wade et al. (1989) and Senthil et al. (2008) that the concentrations of PAHs in these organisms are higher than those of fish and even than in sediments, a very probable reason is that the organisms collected were not adults and had not accumulated large amounts of pollutants in their tissues.

Now, the content of PAHs in muscle tissues of fish species is the result of a multifactorial environmental dynamic and it has been reported that the main route of entry of these hydrocarbons is through food, as well as the water supply that exists. by the filtration they carry out to capture oxygen in their respiratory process. Once PAHs enter an organism, they can accumulate and when these organisms are consumed by others, a biomagnification process is generated through trophic chains (Baqueiro-Cárdenas et al. 2007). According to the eating habits of each of the collected species, they are classified into trophic levels, those of the 1st order are filter feeders such as oysters, those of the 2nd order are herbivores, detritivores and omnivores, they feed on sediment, detritus, plankton, of the 3rd order that feed on the previous levels, in addition to detritus and those of the 4th order that are exclusively carnivorous, so that the contaminants reach them biomagnified.

In this sense, the trophic scheme formed by the species captured in the Tampamachoco lagoon and Tuxpan river, explains the process of contribution and ingestion of PAHs that are accumulated in primary consumers, and that are magnified in higher consumers. Since the highest concentrations were catfish (Bagre marinus) that is classified as 3rd order and in mackerel (Caranx hippos) of 4th order, flathead grey mullet (Mugil curema) and white mojarra (Diapterus auratus) of 2nd order presented intermediate concentrations and oyster Crassostrea virginica of 1 st order presented the lowest concentrations. However, it is important to consider the stages of the reproductive cycle of the species, since it has been in works such as that of Quintero and Díaz (1994) that these stages cause variations in the fat content of muscle tissues and therefore modify the concentrations of quantified PAHs.

In the present study, the analyzed fish species presented the highest concentrations of PAHs in both collections, with significant variations in concentration between march and august, with a tendency to decrease in the rainy season as shown in table 4. 
Table 4. Concentrations of PAHs in organisms of the estuarine-lagoon system Tampamachoco-Tuxpan river Ver. In march, 2018. Values in $\mu \mathrm{g} / \mathrm{g}$ dry weight.

\begin{tabular}{|c|c|c|c|c|c|c|c|c|c|c|c|c|}
\hline \multirow[t]{2}{*}{$\begin{array}{l}\text { No. } \\
\text { Rings }\end{array}$} & \multirow[t]{2}{*}{ Compound } & \multicolumn{2}{|c|}{$\begin{array}{c}\text { Bagre } \\
\text { marinus } \\
\text { Catfish }\end{array}$} & \multicolumn{4}{|c|}{$\begin{array}{c}\text { Diapterus auratus } \\
\text { White Mojarra }\end{array}$} & \multirow{2}{*}{$\begin{array}{c}\begin{array}{c}\text { Caranx } \\
\text { hippos } \\
\text { Mackerel }\end{array} \\
\text { E-4 }\end{array}$} & \multicolumn{3}{|c|}{$\begin{array}{c}\text { Mugil curema } \\
\text { Flathead grey mullet }\end{array}$} & \multirow{2}{*}{$\begin{array}{c}\begin{array}{c}\text { Crassostrea } \\
\text { virginica } \\
\text { Oyster }\end{array} \\
\text { E-2 }\end{array}$} \\
\hline & & E-1 & E-4 & E-2 & E-3 & E-5 & E-6 & & E-2 & E-4 & E-5 & \\
\hline 2 & Nap & N.D. & N.D. & N.D. & N.D & N.D. & N.D. & N.D. & N.D. & N.D. & N.D. & N.D. \\
\hline 2 & Acy & N.D. & 0.04 & N.D. & N.D & N.D. & N.D. & N.D. & N.D. & N.D. & 0.02 & N.D. \\
\hline 2 & Ace & N.D. & N.D & N.D. & N.D & N.D. & N.D. & N.D. & N.D. & N.D. & N.D. & N.D. \\
\hline 2 & Flu & N.D. & N.D & N.D. & N.D & N.D. & N.D. & N.D. & N.D. & N.D. & N.D. & N.D. \\
\hline 3 & Phe & N.D. & N.D & N.D. & N.D & N.D. & N.D. & N.D. & 0.12 & N.D. & 0.11 & N.D. \\
\hline 3 & Ant & N.D. & 0.22 & N.D. & 0.07 & N.D. & N.D. & N.D. & N.D. & ND & N.D. & N.D. \\
\hline 3 & Fla & 0.21 & 0.79 & 0.17 & 0.16 & 0.08 & N.D. & 0.07 & 0.51 & 0.54 & 2.41 & 0.14 \\
\hline 4 & Pir & N.D. & 0.48 & N.D. & N.D. & N.D. & N.D. & N.D. & 0.13 & N.D. & N.D. & 0.04 \\
\hline 4 & $\mathrm{BaA}$ & N.D. & N.D. & N.D. & N.D. & N.D. & N.D. & N.D. & 0.18 & 0.11 & 0.30 & N.D. \\
\hline 4 & Cry & N.D. & 0.15 & N.D. & N.D. & N.D. & N.D. & N.D. & 0.13 & 0.08 & 0.12 & N.D. \\
\hline 4 & $\mathrm{BbF}$ & 28.2 & 0.90 & 4.94 & 8.04 & 5.25 & 6.31 & 51.57 & 19.50 & 19.73 & 40.05 & N.D. \\
\hline 4 & $\mathrm{BkF}$ & N.D. & 86.1 & N.D. & N.D. & N.D. & N.D. & N.D. & N.D. & N.D. & N.D. & N.D. \\
\hline 5 & $\mathrm{BaP}$ & N.D. & 0.16 & 0.47 & N.D. & 0.15 & N.D & N.D. & N.D. & N.D. & N.D. & N.D. \\
\hline 5 & Ind & N.D. & N.D. & 0.84 & N.D. & 0.31 & N.D & N.D. & N.D. & N.D. & N.D. & N.D. \\
\hline 5 & DahA & N.D. & N.D. & N.D. & N.D. & N.D. & N.D & N.D. & N.D. & N.D. & N.D. & N.D. \\
\hline 6 & BghiP & N.D. & N.D. & 0.33 & N.D. & 0.25 & N.D. & N.D. & N.D. & N.D. & N.D. & N.D. \\
\hline \multicolumn{2}{|c|}{$\Sigma$ IPAHs } & 28.4 & 88.8 & 6.75 & 8.27 & 6.04 & 6.31 & 51.64 & 20.57 & 20.46 & 43.01 & 0.18 \\
\hline
\end{tabular}

This behavior could be due to the fact that in the rainy season the contributions (pluvial, fluvial and atmospheric) of water to the lagoon system are greater, which causes the dragging and deposit of pollutants in areas where the flow velocity is lower as occurs in some of the stations sampled, which originated high concentrations in sediments and it would be expected to find a greater amount of PAHs in the water column because the drag of particles can produce the resuspension of the pollutants adhered to them and in this way they can be exported towards the coastal zone, or be kept in suspension for a long period of time according to what was reported by Espinosa et al. (1995). In the case of the Tampamachoco lagoon and Tuxpan river, probably most of the pollutants were deposited in areas of low flow velocity or exported to the coastal zone, therefore, the bioavailability of PAHs dissolved or suspended in the water column it was lower for aquatic species such as fish and therefore, the concentrations detected were lower.

In the dry season the contribution (pluvial, fluvial and atmospheric), the volume of water and the flow velocity decrease, therefore, the concentrations in sediments are lower and it would be expected to find much lower concentrations of PAHs in the dissolved phase of the water since it has been observed that when the current speed decreases the pollutants dispersed in the water column settle and therefore the bioavailability for fish is lower, however, in the present work at this time higher concentrations were detected in fish, which indicates that this is probably due to some local factor such as the traffic of motor boats and boats that circulate through the lagoon channel and the Tuxpan river due to fishing and port activities, which causes PAHs accumulated in the sediments remain in suspension in the water column and therefore, they will be more bioavailable for the fish.

The amount of compounds detected in the different species was 12 in march and 11 in august, and the highest concentrations occurred in March; the compound that appeared the most times in the various species evaluated was benzo(b)fluoranthene, and benzo(k)fluoranthene presented the highest concentration. However, 
it was detected in a single species, in addition to registering fluoranthene, chrysene and benzo(a)anthracene, considered as potential carcinogens and their frequent and abundant consumption may contribute to increasing the risk to human health (Table 4). For the month of August, the same trend was maintained, the compound that was most detected and that presented the highest total concentration was benz (b)fluoranthene, followed by fluoranthene and chrysene (Table 4).

Benzo(b)fluoranthene has been reported in other works as one of the most abundant compounds in various species of fish and it is probably due to; this compound is more easily bioaccumulated than other compounds due to the higher affinity for the lipid tissues of organisms. Another probable reason is that the atmospheric deposition of PAHs is dominated by benzofluoranthenes as reported (Lipíatou et al. 1997), for this reason a greater quantity of these compounds will be found in the water column and they will be more available to aquatic organisms like fish.

The levels of PAHs determined in this study are lower compared to those obtained in other aquatic systems in Mexico, however, it is necessary to monitor the presence of these compounds in the sediments to prevent damage to the benthic organisms that inhabit this system.

The highest concentrations of PAHs in organisms occurred in the dry season and the organisms that presented the highest concentrations in their tissues were: B. marinus, C. hippos and M. curema. Therefore, these species must be subject to continuous surveillance, since they are of high human consumption in the study region. The benthic species $C$. virginica (oyster) presented very low concentrations in both collections, compared to the species of fish and the compound that was most detected in the analyzed species and therefore, the most available in the lagoon system was benzo(b)fluoranthene.

However, it is important to consider the stages of the reproductive cycle of the species analyzed, since this factor causes variations in the fat content of muscle tissue, which will be reflected in the concentrations of PAHs quantified in said tissues.

The trend of accumulation of PAHs in the environmental matrices evaluated was:

$$
\text { Fish }>\text { Sediments }>\text { Oysters }
$$

This trend indicates that a large amount of the pollutants contributed remain in the water column, which is why they are available for aquatic organisms such as fish, therefore higher concentrations are observed in these organisms.

\section{References}

Amador-Muñoz A, Martínez-Domínguez YM, Gómez-Arroyo S, Peralta, O (2020) Current situation of polycyclic aromatic hydrocarbons (PAH) in PM2.5 in a receptor site in Mexico City and estimation of carcinogenic PAH by combining non-real-time and real-time measurement techniques. Science of the Total Environment 703, 134526. https://doi.org/10.1016/j.scitotenv.2019.134526

Arias HA, Vazquez-Botello A, Tombesi N, Ponce-Velez G, Freije H, Marcovecchio J (2010) Presence, distribution, and origins of polycyclic aromatic hydrocarbons (PAHs) in sediments from Bahía Blanca estuary, Argentina. Environ. Monit. Assess. 160, 301e314

Ariese F, Ernst WHO, Sijim DHM (2001) Natural and synthetic organic compounds in the environment -A symposium reports. Environ. Toxicol. Pharm. 10(3):65-80

Baqueiro-Cardenas E, Borabe L, Goldaracena-Islas G, Rodríguez-Navarro J (2007) Los moluscos y la contaminación. Una revisión. Revista Mexicana de Biodiversidad, 78:1S- 7S 
Botello AV, Calva BLG 1998. Polycyclic aromatic hydrocarbons in sediments from Pueblo Viejo, Tamiahua, and Tampamachoco lagoons in the Southern Gulf of México. Bull. Environ. Contam. Toxicol., 60: 96-103

Botello AV, Calva LG, Ponce G (2001) Polycyclic aromatic hydrocarbons in sediments from coastal lagoons of Veracruz State, Gulf of Mexico. Bull. Env. Contam. Toxicol. 67:889-897

Buchman MF (2008) NOAA Screening Quick Reference Tables, NOAA OR\&R Report 08-1. Seattle WA, Office of Response and Restoration Division, National Oceanic and Atmospheric Administration, $34 \mathrm{pp}$

Budzinski H, Jones I, Bellocq J, Piérard C, Garrigues P (1997) Evaluation of sediment contamination by polycyclic aromatic hydrocarbons in the Gironde Estuary. Mar. Chem. 58:85-97

Botello AV (1994) Reporte final del proyecto multidisciplinario: "Evaluación de las lagunas costeras de Pueblo Viejo, Tamiahua y Tampamachoco, Veracruz, para el aprovechamiento y conservación de su biodiversidad". UAM-Iztapalapa, División Ciencias Biológicas y de la Salud. México, $80 \mathrm{p}$

Calva BLG, Botello AV (1999) Polycyclic aromatic hydrocarbons in sediments from Sontecomapan Lagoon, Veracruz, México. Hidrobiológica, 9(1):45-52

Canadian Council of Ministers of the Environment (CCME) (1999) Canadian sediment quality guidelines for the protection of aquatic life: Polycyclic aromatic hydrocarbons (PAHs). In: Canadian environmental quality guidelines, 1999, Canadian Council of Ministers of the Environment, Winnipeg

Chu FL, Volety AK, Hale RC, Huang Y (2002) Cellular responses and disease expression in oysters (Crassostrea virginica) exposed to suspended field-contaminated sediments. Marine Environmental Research, 53:17-35

Espinosa LF, Ramirez G, Campos NH (1995) Análisis de residuos de organoclorados en los sedimentos de zonas de manglar en la cienega grande de Santa Martha y la Bahía de Chengue, Caribe Colombiano. An. Inst. Invest. Mar. Punta Betin, 24:79-94

Furton KG, Pentzke G (1998) Polycyclic Aromatic Hydrocarbons. In: Takayuki, S. (Ed.) Chromatographic Analysis of Environmental and Food Toxicants. Marcel Dekker Inc. Nueva York

Gambaro AM, Radaelli R, Piazza AM, Stortini D, Contini F, Belosi R, Zangrando P (2009) Organic micropollutants in wet and dry depositions in the Venice Lagoon. Chemosphere, 76:1017-1022

GESAMP (IMO/FAO/UNESCO-IOC/WMO/WHO/AIEA/UN/UNEP) Joint Group of Experts on the Scientific Aspects on Marine Environmental Protection) (2001) Protecting the Oceans from Land-based Activities GESAMP Reports and Studies (71):162

Guinan J, Charlesworth M, Service M, Oliver T ( 2001) Sources and geochemical constrains of polycyclic aroamatic hydrocarbons (PAHs) in sediments and mussels of two Northern Irish Sea-loughs. Mar. Pollut. Bull. 42(11):1073-1081

He X, Pang, Song X, Chen B, Feng Z, Ma Y (2014) Distribution, sources and ecological risk assessment of PAHs in surface sediments from Guan River Estuary, China. Mar. Pollut. Bull. 80:52-58

Kim Y, Powell EN, Wade TL, Presley BJ, Brooks JM (2001) The Geographic Distribution of Population Health and Contaminant Body Burden in Gulf of Mexico Oysters. Arch. Environ. Contam. Toxicol., 4:30-46

Lipiatou E, Tolosa I, Simó R, Bouloubassi I, Dachs J, Marti S, Sicre MA, Bayona JM, Grimalt JO, Saliott A, Albaiges J (1997) Mass budget and dynamics of polycyclic aromatic hydrocarbons in the Mediterranean Sea. Deep Sea Research Part II: Tropical Studies in Oceanography, 44:881-905

Long ER, Macdonald DD, Smith SL, Calder FD (1995) Incidence of adverse effects within ranges of chemical concentrations in marine and estuarine sediments. Environmental Management 19(1), 81-97 
Mastandrea C, Chichizola C, Luduena B (2005) Hidrocarburos Aromáticos Policíclicos. Riesgos para la salud y marcadores biológicos. Acta. Bioquím. Clín. Latinoam. 39(1): 27-36

Noreña-Barroso E, Gold-Bouchot G, Ceja-Moreno V (2007). Temporal variation of persistent organic pollutant (POP) residue concentrations in sediments from the Bay of Chetumal, Mexico. Bull. Environ. Contam. Toxicol., 79:141-146

Ponce-Vélez G (2012) Los contaminantes orgánicos persistentes en la laguna El Yucateco, Tabasco, México: una década de estudio. Tesis de Doctorado. Posgrado en Ciencias de la Tierra, UNAM. Ciudad de México. $260 \mathrm{p}$

Quintero S, Díaz C (1994) Hidrocarburos aromáticos policíclicos en peces de aguas costeras canarias. Sci. Mar., 58(4): 307-313

Ramos I, Fuentes M, Mederos R, Grimalt RO, Albaiges J (1989) Dissimilar microbial hydrocarbon transformation processes in the sediment water column of a tropical bay (Havana Bay, Cuba), Marine Pollution Bulletin, 20:262-268

Sammarco PW, Kolian SR, Warby RAF, Bouldi JL, Subra WA, Porter SA (2013) Distribution and concentration of petroleum hydrocarbons associated with the BP/Deepwater Horizon spill, Gulf of Mexico. Mar.Pollut.Bull. 73: 129-143

Senthil K, Sajwan KS, Richardson JP, Kannan K (2008) Contamination profiles of heavy metals, organochlorine pesticides, polycyclic aromatic hydrocarbons and alkylphenols in sediment and oyster collected from marsh/estuarine Savannah GA, USA. Marine Pollution Bulletin, 56:136-162

Soclo HH, Garrigues PH, Ewald M (2000) Origin of Polycyclic Aromatic Hydrocarbons (PAHs) in Coastal Marine Sediments: Case Studies in Cotonou (Benin) and Aquitaine (France) Areas. Marine Pollution Bulletin 40(5), 387-396

Tolosa I, Mesa-Albernas M, Alonso- Hernandez CM (2009). Inputs and sources of hydrocarbons in sediments from Cienfuegos Bay, Cuba. Mar. Pollut.Bull. 58:1624-1634

UNEP/IOC/IAEA (1992) Determination of Petroleum Hydrocarbons in Sediments. Reference Method for Marine Pollution Studies no. 20. United Nations Experts Pollution (UNEP)

UNEP/FAO/IOC/IAEA (1993) Guidelines for Monitoring Chemical Contaminants in the Sea using Marine Organisms. Reference Method No. 6. United Nations Experts Pollution (UNEP)

USEPA (2001) Method 3546 for the Extraction of Contaminants Under Closed Vessel Conditions. Paré, J.R.J., Bélanger, J.M.R., Lesnik, B., Turpin, R., Singhvi, R. Final Evaluation of US EPA Method 3546. Soil and Sediment Contamination: An International Journal, 10:4, 375-386

Wade TL, Kennicutt MC, Brooks JM (1989) Gulf of Mexico hydrocarbon seep communities: Part III. Aromatic hydrocarbon concentrations in organisms, sediments and water. Marine Environmental Research, 27:19-30

Wu Y, Zhang J, Zhu Z (2003) Polycyclic aromatic hydrocarbons in the sediments of the Yalujiang Estuary, North China. Marine Pollution Bulletin, 46:619-625

Yunker MB, MacDonald RW, Vingarzam R, Mitchell RH, Goyette D, Sylvestre S (2002) PAHs in the Fraser river basin: a critical appraisal of PAH ratios as indicators of PAH sources and composition. Org. Geochem. $33,489-5$ 